\title{
PERLINDUNGAN HUKUM POTENSI INDIKASI GEOGRAFIS DI KABUPATEN BREBES GUNA PENGEMBANGAN EKONOMI MASYARAKAT LOKAL
}

\author{
Siti Asfiyah \\ Magister Hukum, Fakultas Hukum Universitas Jenderal Soedirman
}

\begin{abstract}
Geographical indication is one part of the intellectual property rights since the last decade began to be developed by countries in the world. Geographical indications play a role vital in giving the impression to the consumers about the existence of more value on products offered, both about the quality as well as properties that can enhance the competitiveness of a product, because the IG is beneficial increasing competitiveness strong enough in the market. Legal Sciences approach used in this study, the research is a descriptive analytical specifications. The type of the data are primary data and secondary data. Methods of data analysis used is normative qualitative. The results of studies on legal protection of potential IG in Brebes Regency, that Bradford has a range of potential that can be protected by the IG are: Brebes onion, Brebes eggs, black rice salted Sirampog and black tea Kaligua. Brebes Regency Government does not yet have a clear format about the development potential of the IG, yet there is one special area regulations to govern the IG and dig out the potential in Brebes Regency is an issue that must be resolved by the District Government. The community has not been registering potential IG Brebes and Brebes Regency Government also does not yet have a specific local regulations to protect IG potential legal protection then the County Brebes refers to the rules that apply in General, so that legal protection potential of Brebes Regency IG can be done with: Preventive legal protection and Repressive judicial protection. Brebes Regency society has not taken protective measures at all against a potential IG in its territory, because the weakness of the legal society awareness and lack of socialization of Dit HKI.
\end{abstract}

\section{PENDAHULUAN}

Indikasi geografis (selanjutnya disingkat IG) adalah salah satu bagian dari Hak Kekayaan Intelektual yang sejak dasawarsa terahir mulai dikembangkan oleh negara-negara di dunia. IG adalah tanda yang digunakan untuk produk yang mempunyai asal geografis spesifik dan mempunyai kualitas atau reputasi yang berkaitan dengan asalnya. Pada umumnya IG terdiri dari nama produk yang diikuti dengan nama daerah atau tempat asal produk. ${ }^{1}$
IG pertama kali diatur dalam Konvensi Paris 1883, pada konvensi ini diperkenalkan langkah-langkah protektif pada Border of Measures dan perlindungan terhadap persaingan usaha tidak sehat (unfair competition). Selain itu diatur juga dalam Madrid Agreement 1891 False Indication and Border Of Measures. Selanjutnya Perjanjian Lisabon sebagai perlindungan Indikasi Asal tahun 1958 yang mengatur registrasi internasional atas Indikasi Asal. IG dalam Trade Related Aspects of Intellectual Property Rights

\footnotetext{
Saky Septiono, Perlindungan Indikasi Geografis dan Potensi Indikasi Geografis Indonesia, www.dgip.go.id/ indikasi-geografis, diakses 12 Nopember 2013
} 
(selanjutnya disebut TRIPs) yang ditandatangani pada Putaran Uruguay General Agreement On Tarifs and Trade (selanjutnya disebut GATT) tahun 1994 menawarkan kesempatan yang sangat luas untuk perlindungan internasional bagi IG. ${ }^{2}$ Tanggal 15 April 1994 Indonesia turut menandatangani perjanjian ini dan disahkan dengan dibentuknya Undang-Undang (selanjutnya disebut UU) Nomor 7 tahun 1994 Tentang Pengesahan Agreement Establising The World Trade Organization.

Konsekuensi yuridis dari diratifikasinya perjanjian TRIP's adalah Indonesia harus membuat payung hukum tentang IG. Pemerintah berupaya membuat payung hukum IG dimulai dengan dikeluarkannya UU Nomor 14 Tahun 1997 tentang Merek, karena tidak mengalami perkembangan sama sekali dalam praktekya, kemudian tahun 2001 UU Nomor 14 Tahun 1997 tersebut dicabut dan dinyatakan tidak berlaku lagi dan diganti dengan UU Nomor 15 Tahun 2001 tentang Merek (selanjutnya disebut UUM). Ketentuanketentuan tentang IG dalam UUM pada praktiknya tidak berjalan karena tidak ada Peraturan Pemerintah (selanjutnya disebut PP) sebagai implementasi dari ketentuan pasal-pasal tentang IG dalam UUM, selanjutnya pada tahun 2007 disahkanlah PP Nomor 51 tahun 2007 tentang Pendaftaran IG sebagai wujud pelaksanaan atau implementasi dari UUM.

UUM menentukan bahwa IG akan mendapat perlindungan setelah terdaftar, sedangkan ketentuan mengenai tata cara pendaftaran IG diatur lebih lanjut dengan PP. Adapun syarat dan tata

2 Workshop "Geographical Indication In Indonesia" Media HKI Depkumham, vol II/No.1 April 2004, hlm. 27-28 cara permohonan diatur dalam pasal 5 dan 6 PP Nomor 51 tahun 2007 tentang Pendaftaran IG. ${ }^{3}$

Pasal 5 ayat

(1) Permohonan diajukan secara tertulis dalam bahasa Indonesia oleh Pemohon atau melalui Kuasanya dengan mengisi formulir dalam rangkap 3 (tiga) kepada Direktorat Jenderal

(2) Bentuk dan isi formulir permohonan sebagaimana dimaksud dalam ayat (1) ditetapkan oleh Direktorat Jenderal

(3) Pemohon sebagaimana dimaksud pada ayat (1) terdiri atas

a. Lembaga yang mewakili masyarakat di daerah yang memproduksi barang yang bersangkutan, terdiri atas:

1. Pihak yang mengusahakan barang hasil alam atau kekayaan alam

2. Produsen barang hasil pertanian

3. Pembuat barang hasil kerajinan tangan atau barang hasil industri; atau

4. Pedagang yang menjual barang tersebut

b. Lembaga yang diberi kewenangan untuk itu; atau

c. Kelompok konsumen barang tersebut

Pasal 6

(1) Permohonan sebagaimana dimaksud pasal 5 harus mencantumkan persyaratan administrasi sebagai berikut:

a. Tanggal, bulan dan tahun

b. Nama lengkap, kewarganegaraan dan alamat pemohon; dan

c. Nama lengkap dan alamat kuasa, apabila permohonan diajukan melalui kuasa

(2) Permohonan sebagaimana dimaksud ayat (1) harus dilampiri;

a. Surat kuasa khusus, apabila permohonan diajukan melalui kuasa; dan

b. Bukti pembayaran biaya

(3) Permohonan sebagaimana dimaksud ayat (1) harus dilengkapi dengan buku persyaratan yang terdiri atas:

a. Nama Indikasi-geografis yang dimohonkan pendaftarannya

b. Nama barang yang dilindungi Indi-kasigeografis

\footnotetext{
${ }^{3}$ Peraturan Pemerintah Nomor 51 Tahun 2007 Tentang Indikasi Geografis
} 
c. Uraian mengenai karakteristik dan kualitas yang membedakan barang tertentu dengan barang lain yang memiliki kategori sama, dan menjelaskan tentang hubungannya dengan daerah tempat barang tersebut dihasilkan

d. Uraian mengenai lingkungan geografis serta faktor alam dan faktor manusia yang merupakan satu kesatuan dalam memberikan pengaruh terhadap kualitas atau karakteristik dari barang yang dihasilkan

e. Uraian tentang batas-batas daerah dan/atau peta wilayah yang dicakup oleh Indikasi-geografis

f. Uraian mengenai sejarah dan tradisi yang berhubungan dengan pemakaian Indikasi-geografis untuk menandai barang yang dihasilkan di daerah tersebut, termasuk pengakuan dari masyarakat mengenai Indikasi-geografis tersebut

g. Uraian yang menjelaskan tentang proses produksi, proses pengolahan dan proses pembuatan yang digunakan sehingga memungkinkan setiap produsen di daerah tersebut untuk memproduksi, mengolah atau membuat barang terkait

h. Uraian mengenai metode yang digunakan untuk menguji kualitas barang yang dihasilkan; dan

i. Label yang digunakan pada barang dan memuat Indikasi-geografis

(4) Uraian tentang batas-batas daerah dan/atau peta wilayah yang dicakup oleh Indikasi Geografis sebagaimana dimaksud pada ayat (3) huruf e harus mendapat rekomendasi dari instansi yang berwenang.

Indikasi geografis memberikan perlindungan terhadap tanda yang mengidentifikasikan suatu wilayah negara, atau kawasan atau daerah didalam wilayah tersebut sebagai asal barang, dimana reputasi, kualitas dan karakteristik barang tersebut sangat ditentukan oleh faktor geografis yang bersangkutan. Ciri dan kualitas barang yang dipelihara dan dapat dipertahankan dalam jangka waktu tertentu akan melahirkan reputasi atas barang tersebut, yang selanjutnya memungkinkan barang tersebut memiliki nilai ekonomi tinggi.

Indonesia adalah negara dengan keragaman budaya dan sumberdaya alam, banyak produk unggulan yang dihasilkan dan mendapat tempat dipasar internasional, sudah seharusnya Indonesia memiliki sistem perlindungan IG yang memadai. Melalui perlindungan IG yang optimal tidak saja kelestarian lingkungan diharapkan dapat terjaga, pemberdayaan sumber daya alam dan manusia didaerah diharapkan dapat lebih dimaksimalkan. Disamping itu, migrasi tenaga kerja potensial dari suatu daerah kedaerah perkotaan diharapkan dapat dicegah, dengan terbukanya peluang dan lapangan kerja untuk menghasilkan barang tertentu yang dilindungi dengan IG dan diharapkan memiliki nilai ekonomi tinggi didaerah tersebut sehingga ekonomi lokal dapat dikembangkan dengan baik. ${ }^{4}$ Lebih dari itu, perlindungan IG dapat memposisikan produk-produk tradisional Indonesia dengan lebih baik dalam konteks perdagangan regional dan internasional, terutama setelah diberlakukannya ASEAN Free Trade Agreement (AFTA) dan ASEAN-China Free Trade Agreement (ACFTA) yang berlaku sejak tanggal 1 Januari 2010.

Kabupaten Brebes merupakan salah satu Kabupaten yang ada di wilayah Provinsi Jawa Tengah. Kabupaten Brebes merupakan daerah strategis yang mempunyai potensi cukup besar dalam pengembangan sumber daya alam. Sejalan dengan diterapkannya otonomi daerah, maka hampir setiap daerah otonom dihadapkan pada 
suatu permasalahan, antara lain bagaimana upaya menciptakan pendapatan asli daerah (PAD) guna membiayai kelangsungan jalannya roda pemerintahan daerah dan di sisi lain bagaimana menumbuhkembangkan inovasi dan kreatifitas masyarakat agar mampu menjaga kelestarian lingkungan serta mampu melindungi dan menghidupi kebutuhan hidupnya. Selain itu agar dapat pula menghadapi perkembangan keadaan, baik di dalam maupun di luar negeri khususnya dalam menghadapi persaingan global. ${ }^{5}$

Diantara potensi daerah Kabupaten Brebes yang menurut peneliti layak untuk di daftarkan IG nya adalah dari sektor perkebunan yaitu Perkebunan Teh Kaligua penghasil Teh Hitam (Black Tea). Sektor Pertanian yaitu Bawang Merah Brebes dan Beras Hitam Sirampog. Sektor Peternakan itik penghasil telur asin Brebes. Dari ke empat (4) potensi IG yang ada, hanya perkebunan teh yang dikelola oleh BUMN selebihnya adalah milik masyarakat.

Sektor Perkebunan yang memiliki karakteristik adalah perkebunan Teh Kaligua, yang dikembangkan juga menjadi kawasan wisata agro dataran tinggi yang terletak di Desa Pandansari, Kecamatan Paguyangan. Luas perkebunan teh Kaligua 1600 hektar yang menghasilkan 5.200 ton per tahun teh hitam siap ekspor ke Eropa dan Timur Tengah.

Produksi telur asin Brebes tidak terlepas dari potensi Kabupaten Brebes sebagai penghasil telur

5 Noegroho Amien Soetiarto, Hak Kekayaan Intelektual dan Kekayaan Intelektual Tradisional dalam Konteks Otonomi Daerah, Mimbar Hukum Nomor 34/II/2000

6 Wawancara prasurvey dengan Endang listyowati, Kabid Tekhnologi Industri Kantor Dinas Perindustrian dan Perdagangan Kabupaten Brebes, tanggal 9 Desember 2013. bebek yang cukup melimpah untuk dijadikan bahan baku utama pembuatan telur asin. Produsen telur asin di Kabupaten Brebes cukup besar, mencapai kisaran 200 produsen telur asin, dengan jumlah produksi rata-rata 2000 butir per produsen perbulan. Untuk produsen yang memiliki skala usaha menengah atau besar, produksinya bisa mencapai 10.000 butir perbulan. Produksi telur asin di Kabupaten Brebes, dilaksanakan oleh para produsen yang tergabung dalam suatu klaster komoditas telur asin dengan komposisi 1 pengusaha skala besar, 14 orang pengusaha kelompok menengah dan 85 pengusaha kelompok kecil. ${ }^{6}$

Telur asin Brebes memiliki karakteristik dan ciri khas rasa tertentu dan berbeda dari daerah lain. Hal ini karena telur asin Brebes dibuat dengan tekhnologi sederhana yang terdiri dari komponen dan langkah-langkah tertentu yang tentunya berbeda dengan daerah lain. Menurut salah satu produsen telur asin, bahwa tanah liat dan bata merah yang ada di Brebes memiliki kandungan berbeda dengan tanah liat dari daerah lain. Inilah yang membuat rasa telur asin Brebes memiliki ciri khas rasa tersendiri. ${ }^{7}$ Karena karakteristik tersebut, sehingga layak untuk di daftarkan sebagai IG.

Sektor Pertanian yaitu Bawang Merah Brebes dan Beras Hitam Sirampog. Bawang Merah Brebes merupakan salah satu produk andaIan dan unggulan Kabupaten Brebes, Kabupaten Brebes memberikan kontribusi $38,2 \%$ dari produksi

\footnotetext{
Wawancara prasurvey dengan Bapak Komarudin, produsen Telur Asin "HTM Jaya", tanggal 9 Desember 2013
} 
nasional atau $79,1 \%$ dari produksi bawang merah di Jawa Tengah. Produksi bawang merah Indonesia pada tahun 2012 mencapai 960.072 ton di pasok oleh Kabupaten Brebes sebesar 326.424 ton. Bawang merah bagi Kabupaten Brebes merupakan trademark mengingat posisinya sebagai penghasil terbesar komoditi tersebut didataran nasional serta memiliki brand image yang baik bagi konsumen bawang merah di Indonesia. Bawang merah Brebes terkenal dengan kualitas yang baik dari bawang merah yang berasal dari daerah lain di Indonesia atau luar negeri seperti Thailand dan China. Bawang merah asli Brebes memiliki cita rasa tinggi, yaitu lebih menyengat dan harum serta produk jadi (bawang goreng) lebih enak dan gurih. ${ }^{8}$

Beras Hitam bagi sebagian masyarakat Indonesia belum banyak yang mengenal. Beras Hitam selain mengandung nilai gizi yang tinggi juga dapat dijadikan obat diantaranya membersihkan kolesterol dalam darah, memperbaiki kerusakan pada hati, mencegah kerusakan pada ginjal dan meningkatkan ketahanan tubuh pada penyakit. Beras ini bisa ditanam dan didapatkan didataran tinggi (1000-1500 mdpl) salah satunya di Desa Kaligiri Kecamatan Sirampog. Beras Hitam merupakan salah satu potensi pertanian di Kecamatan Sirampog yang sulit dijumpai di daerah lain. Ada sekitar 6 hektar lahan yang ditanami beras hitam dan dari perhektarnya dapat menghasilkan sekitar 4-5 ton dengan harga Rp 15.000/kg. Keunikan serta kandungannya yang dipercaya memiliki man-

8 Kelebihan Bawang Merah dari Lumbung Bawang Merah Brebes, Pasarbawang-brebes.blogspot.com, diakses 28 Nopember 2013.

9 Dhani, Beras Hitam Asal Sirampog, Wangi dan Berkhasiat Bagi Kesehatan,www.KoranLokal.com, 14 Juni 2011, diakses tanggal 17 Nopember 2013 faat bagi kesehatan adalah potensi yang sangat perlu untuk dikembangkan. ${ }^{9}$

Berdasarkan pendapat tersebut diatas, untuk mengantisipasi adanya pihak-pihak yang tidak bertanggung jawab terhadap penggunaan IG dan adanya persaingan curang, maka pendaftaran IG mutlak dilakukan karena sampai dilakukannya penelitian ini belum satupun potensi IG di Kabupaten Brebes yang didaftarkan ke Ditjen HKI, padahal pada tahun 2010 dari Ditjen HKI pernah melakukan penyuluhan tentang IG di Kabupaten Brebes namun belum ada respon dari masyarakat maupun pemerintah daerah. ${ }^{10}$

Pemerintah Daerah Kabupaten Brebes (selanjutnya disebut Pemkab) hendaknya melakukan upaya-upaya untuk memahamkan kepada masyarakat akan pentingnya pendaftaran IG, supaya pengalaman suram dimasa lalu yaitu didaftarkannya IG Kopi Toraja Sulawesi Selatan oleh Key Coffe di Jepang dengan merek "Toarco Toraja" lengkap dengan rumah adat masyarakat Tanah Toraja sebagai mereknya tidak terulang kembali dan ekonomi lokal di Kabupaten Brebes dapat dikembangkan dengan baik, karena kekuatan ekonomi lokal (UKM) telah terbukti mampu bertahan dan tahan banting walaupun menghadapi krisis moneter.

Pemerintah Daerah Kabupaten Brebes perlu mengambil kebijakan dalam rangka memberikan jaminan perlindungan akan hak IG yang ada di Kabupaten Brebes sebagai wujud kepedulian terhadap kekayaan daerah yang ada, mengingat

10 Wawancara Prasurvey dengan Bapak Idris, Fungsional Umum Subdit. IG Ditjen HKI Tangerang, Tanggal 24 Desember 2013 
masih banyak komoditas atau produk yang potensial dilindungi sebagai IG belum mendapatkan perhatian yang memadai dari pemerintah, terutama Pemerintah Daerah sebagaimana diamanatkan oleh Undang-Undang Nomor 15 Tahun 2001 Tentang Merek dan PP Nomor 51 Tahun 2007. Pemerintah Daerah Kabupaten Brebes perlu meningkatkan Pendapatan Asli daerah (PAD) dan meningkatkan kesejahteraan masyarakat, mengingat telah beberapa tahun terahir ini Kabupaten Brebes tercatat menjadi Kabupaten termiskin urutan ke 35 dari 35 Kabupaten dengan jumlah Rumah Tangga Miskin sebanyak 21,12 \% atau sejumlah 364.900 jiwa (2011) di Jawa Tengah. ${ }^{11}$ Banyaknya Potensi daerah yang ada di Kabupaten Brebes yang dapat dilindungi dengan IG, diharapkan dapat meningkatkan pengembangan ekonomi lokal agar kesejahteraan masyarakat dapat ditingkatkan dengan banyak terbukanya peluang usaha baru.

\section{RUMUSAN MASALAH}

Hal inilah yang melatar belakangi peneliti untuk mengkaji lebih dalam bagaimana perlindungan hukum potensi Indikasi Geografis di Kabupaten Brebes guna pengembangan ekonomi masyarakat lokal dan bagaimana upaya masyarakat ${ }^{12}$ Kabupaten Brebes dalam melindungi Potensi Indikasi Geografis.

\footnotetext{
${ }^{11}$ Hendrik, Brebes Rangking Teratas Soal Kemiskinan di Jawa Tengah, Brebesnews.co/2013/brebes-rangking-teratas, 25 Oktober 2013, diakses tanggal 15 Nopember 2013

${ }^{12}$ Masyarakat adalah semua komponen yang ada di PP.No.51 tahun 2007 pasal 5 ayat (3) tentang Pendaftaran IG

${ }^{13}$ Ronny Hamitijo Soemitro, 1990, Metode Penelitian Hukum dan Jurimetri, Ghalia Indonesia, Jakarta, hlm. 35

${ }^{14}$ Sistem Konstitutif, pendaftaran merupakan keharusan agar dapat memperoleh hak atas merek. Tanpa pendaftaran
}

\section{Metode Penelitian}

Penelitian ini menggunakan pendekatan yuridis sosiologis. Pendekatan yuridis sosiologis dimaksudkan sebagai penerapan dan pengkajian hubungan aspek hukum dan non hukum dalam bekerjanya hukum dimasyarakat. ${ }^{13}$ Tipe Penelitian adalah deskriptif analitis, Jenis data menggunakan data primer dan data sekunder, metode pengumpulan data adalah studi kepustakaan dan penelitian lapangan. Metode analisis data kualitatif

\section{A. Hasil Penelitian dan Pembahasan}

\section{Perlindungan Hukum Potensi IG di Kabupaten Brebes Guna Pengembangan Ekonomi Masyarakat Lokal}

Menurut ketentuan UUM pasal 56 bahwa IG akan memperoleh perlindungan hukum jika sudah didaftarkan, karena dalam ketentuan UUM dikenal sistem pendaftaran konstitutif $^{14}$ yang memberi perlindungan hak hanya kepada pendaftar pertama, dan pendaftar berikutnya tidak akan memperoleh perlindungan hukum. Perlindungan hukum terhadap potensi IG di Kabupaten Brebes menurut ketentuan UUM adalah melalui pendaftaran di Ditjen HKI.

Philipus M. Hadjon, mengatakan bahwa perlindungan hukum bagi rakyat terdapat dua macam bentuk perlindungan hukum yaitu pertama perlindungan hukum preventif artinya rakyat diberi kesempatan mengajukan pendapatnya sebelum

\footnotetext{
negara tidak akan memberikan hak atas merek kepada pemilik merek. Hal ini berarti tanpa pendaftaran merek, seseorang tidak akan diberikan perlindungan hukum oleh negara apabila mereknya ditiru oleh orang lain. Rachmadi Usman, 2003, Hukum Hak atas Kekayaan Intelektual, Perlindungan dan Dimensi Hukumnya di Indonesia, Alumni, Bandung, hlm. 326
} 
keputusan pemerintah mendapat bentuk yang definitive yang bertujuan untuk menghindari terjadinya sengketa. Kedua adalah perlindungan hukum represif yang bertujuan menyelesaikan sengketa. ${ }^{15}$ Kaitannya dengan perlindungan IG yaitu:

1. Perlindungan hukum preventif bersifat untuk mencegah, mengantisipasi adanya pelanggaran terhadap IG maka UUM Jo PP No.51 tahun 2007 memberikan perlindungan hukum baik perdata maupun pidana

2. Perlindungan hukum represif bertujuan untuk menyelesaikan sengketa, jika terjadi penyalahgunaan IG oleh pihak lain maka pemilik atau pemegang hak atas IG berhak mengajukan gugatan ganti rugi kepada Pengadilan Niaga karena pelanggaran hak atas IG atau pemakaian IG secara tanpa hak atau melawan hukum

Perlindungan hukum preventif bagi IG bawang merah Brebes, telur asin Brebes, teh hitam kaligua dan beras hitam sirampog adalah dengan cara mendaftarkannya ke Ditjen HKI, hal ini sesuai dengan teori perlindungan HKI Robert $M$. Sherwood yang pertama yaitu Reward Theory yang memiliki makna mendalam berupa pengakuan terhadap karya intelektual yang telah dihasilkan oleh seseorang sehingga kepada penemu/pencipta atau pendesain harus diberikan penghargaan sebagai imbangan atas upaya-upaya kreatifnya dalam menemukan atau menciptakan karya-karya intelektual tersebut. Perlindungan terhadap potensi IG untuk menikmati manfaat ekonomi atas potensi IG merupakan salah satu wujud dari penghargaan dan pengakuan oleh pemerintah atas keberhasilan masyarakat pemilik IG bawang merah Brebes, telur asin Brebes, teh hitam Kaligua dan beras hitam Sirampog dalam menemukan atau mengembangkan produk yang berpotensi IG tersebut. Perlindungan IG ini belum memiliki UU tersendiri akan tetapi masih bernaung dibawah UU merek. Reward diberikan ketika masyarakat pemilik IG mendaftarkan produk potensi IG tersebut kepada Ditjen HKI sehingga apabila produk yang berpotensi IG tersebut memenuhi unsur-unsur IG maka masyarakat pemilik IG akan mendapatkan reward berupa sertifikat IG. Sertifikat IG ini sebagai wujud dari penghargaan dan pengakuan oleh pemerintah atas keberhasilan masyarakat pemilik IG bawang merah Brebes, telur asin Brebes, teh hitam kaligua dan beras hitam sirampog dalam menemukan atau mengembangkan produk yang berpotensi IG.

\section{Sejalan dengan teori diatas yaitu Recovery} Theory yang merupakan teori kedua dari Robert M Sherwood yaitu prinsip yang menyatakan bahwa penemu/pencipta/pendesain yang telah mengeluarkan waktu, biaya serta tenaga untuk menghasilkan karya intelektualnya harus memperoleh kembali apa yang telah dikeluarkannya. Perlindungan IG hanya dapat diakui setelah didaftarkan. Sampai dengan penelitian ini dilakukan tahun 2013 belum terbentuknya organisasi pemerhati bawang merah Brebes, telur asin Brebes, teh hitam kaligua dan beras hitam sirampog. Padahal wadah atau organisasi ini merupakan tonggak awal pendaftaran IG. 
Belum terbentuknya organisasi atau lembaga yang secara khusus pemerhati bawang merah Brebes, telur asin Brebes, teh hitam kaligua dan beras hitam sirampog juga akan berdampak pada penyusunan buku persyaratan IG, karena buku persyaratan merupakan prasyarat utama pendaftaran yang harus di isi oleh organisasi atau lembaga tersebut, dasar pertimbangannya adalah bahwa: ${ }^{16}$

1. Yang dapat memberikan uraian mengenai sejarah dan tradisi yang berhubungan dengan pemakaian IG untuk menandai barang yang dihasilkan didaerah tersebut adalah menjadi kompetensi masyarakat petani.

2. Peran kelompok konsumen dalam memberikan pengakuan mengenai IG dan menjadi keuntungan konsumen apabila produk yang dikonsumsi dijamin keasliannya.

3. Menjadi kompetensi Dinas Pertanian untuk memberikan uraian mengenai karakteristik khas dan kualitas yang membedakan barang barang tertentu dengan barang lain yang memiliki kategori sama, dan menjelaskan tentang hubungannya dengan daerah tempat barang tersebut dihasilkan, uraian mengenai pengaruh lingkungan geografis dan alam serta faktor manusia terhadap kualitas atau karakteristik barang tersebut dan uraian tentang batas-batas wilayah dan atau peta daerah yang dilindungi oleh IG.

4. Pedagang atau pengusaha atau bandar terkait dengan kompetensinya menjelaskan tentang proses produksi, proses pengolahan, proses pembuatan yang digunakan sehingga memungkinkan setiap produsen didaerah tersebut dapat memproduksi, mengolah, atau membuat barang terkait.

5. Bagian hukum Pemda dimana produk IG tersebut berada untuk pengurusan birokrasi pemerintahan.

\footnotetext{
${ }^{16}$ Tatty Ramli dan Yetti Sumiati, Implikasi Pendaftaran Indikasi Geografis, Op.Cit. hlm 74
}

Penunjukan lembaga pemerintah untuk berkoordinasi dengan lembaga yang ada di masyarakat termasuk kelompok konsumen semata-mata ditujukan kepada fungsinya sebagai pengayom, pelindung, dan pelaksana kesejahteraan masyarakat dengan cara mengelola dan memberdayakan secara optimal manfaat ekonominya. ${ }^{17}$

Apabila bawang merah Brebes, telur asin Brebes, teh hitam Kaligua dan beras hitam Sirampog telah didaftarkan dan telah mengisi buku persyaratan serta dianggap layak dan memenuhi unsur-unsur IG maka masyarakat pemilik IG bawang merah Brebes, telur asin Brebes, teh hitam Kaligua dan beras hitam Sirampog akan mendapatkan sertifikat IG. Setelah mendapatkan sertifikat IG maka sertifikat tersebut dapat digunakan untuk meningkatkan penjualan bawang merah Brebes, telur asin Brebes, teh hitam Kaligua dan beras hitam Sirampog, karena masyarakat tidak akan ragu lagi dengan kualitas produk yang telah mendapatkan sertifikat IG dan bersedia membayar dengan harga mahal sekalipun. Selain itu dapat pula digunakan untuk meningkatkan pemasaran produk baik di dalam negeri maupun luar negeri.

Masyarakat pemilik IG bawang merah Brebes, telur asin Brebes, teh hitam Kaligua dan beras hitam Sirampog akan mendapatkan kembali semua biaya, waktu, tenaga dan jerih payah yang telah dikeluarkan dengan mendapatkan sertifikat IG yang dapat digunakan untuk meningkatkan pemasaran dan penjualan produknya sehingga

\footnotetext{
${ }^{17}$ Edi Damian dalam Tatty Ramli dan Yetti Sumiati, Implikasi Pendaftaran Indikasi Geografis, Ibid
} 
dapat meningkatkan ekonomi masyarakat lokal Kabupaten Brebes.

Teori Robert M. Sherwood yang ketiga yang sejalan dengan kedua teori diatas adalah Incentive Theory memiliki makna bahwa insentif perlu diberikan untuk mengupayakan terpacunya kegiatan-kegiatan penelitian yang berguna. Dalam perlindungan IG keuntungan yang akan didapat oleh petani sebagaimana dikemukakan oleh Emawati Junus adalah: ${ }^{18}$

1. Meningkatkan profesionalisme petani (karena disyaratkan adanya buku spesifikasi untuk menjamin kualitas)

2. Meningkatkan dan memlihara produk IG dan memperkuat daya saing petani

3. Memperkuat hak petani melalui asosiasi produk IG

4. Mendorong peningkatan pemerataan ekonomi yang lebih baik bagi para petani

5. Meningkatkan dan menciptakan lapangan kerja bagi para petani didaerah yang memiliki potensi produk IG

Ketiga teori diatas pada intinya memiliki visi yang sama berupa pemberian penghargaan kepada para penemu atau pencipta atau pendesain, dalam penelitian ini adalah kepada petani bawang merah Brebes atas karya intelektual yang telah dihasilkannya. Perlindungan preventif disini sangat diperlukan untuk mengantisipasi adanya kecurangan dari pihak lain yang tidak bertanggung jawab, karena HKI khususnya IG dapat mendatangkan manfaat ekonomi bagi pemiliknya.

HKI merupakan hasil karya yang mengandung resiko, seperti halnya potensi IG bawang merah Brebes, telur asin Brebes, teh hitam Kaligua dan beras hitam sirampog. Perlindungan

${ }^{18}$ Emawati Junus, 2007, Makalah PPT dalam Pentingnya Perlindungan Indikasi Geografis Sebagai Bagian dari HKI hukum represif sangat diperlukan untuk mengantisipasi adanya sengketa penyalahgunaan IG oleh pihak lain maka pemilik atau pemegang hak atas IG berhak mengajukan gugatan ganti rugi kepada Pengadilan Niaga karena pelanggaran hak atas IG atau pemakaian IG secara tanpa hak atau melawan hukum. Hal ini sesuai dengan teori Robert M. Sherwood yang keempat yaitu Risk Theory. HKI merupakan suatu penelitian yang mengandung resiko yang dapat memungkinkan orang lain yang terlebih dahulu menemukan cara tersebut atau memperbaikinya; dengan demikian adalah wajar memberikan perlindungan hukum terhadap upaya atau kegiatan yang mengandung resiko tersebut. IG memperoleh perlindungan hukum adalah melalui pendaftaran. Sampai dengan penelitian ini dilakukan potensi IG bawang merah Brebes, telur asin Brebes, teh hitam Kaligua dan beras hitam Sirampog belum didaftarkan. Jika suatu hari nanti IG bawang merah Brebes, telur asin Brebes, teh hitam Kaligua dan beras hitam Sirampog yang belum didaftarkan oleh masyarakat Brebes ternyata telah digunakan oleh pihak lain secara tanpa hak sebagaimana dimaksud dalam pasal 25 PP No. 51 Tahun 2007, maka pemilik IG yang bersangkutan dapat mengajukan klaim pembatalan sebagaimana dimaksud dalam pasal 57 UUM. Namun sebelum klaim diajukan masyarakat pemilik IG yang belum terdaftar harus mengajukan pendaftaran IG di Ditjen HKI untuk mendapatkan kepastian perlindungan hukum.

Teori yang sejalan dengan teori diatas yang merupakan teori terahir dari Robert M. Sherwood adalah Economic Growth Stimulus Theory, teori

dan Pelaksanannya di Indonesia, Ditjen HKI, Jakarata, hlm. 12 
ini mengakui bahwa perlindungan atas $\mathrm{HKI}$ adalah merupakan suatu alat dari pembangunan ekonomi, berupa keseluruhan tujuan dibangunnya suatu sistem perlindungan atas HKI yang efektif. Teori ini relevan untuk dijadikan dasar perlindungan HKI saat ini terutama dalam menghadapi era perdagangan bebas dan konsekuensi diratifikasinya kesepakatan WTO oleh Indonesia. Konsekuensi tersebut mengharuskan Indonesia memiliki sistem perlindungan $\mathrm{HKI}$ yang memadai baik bagi HKI nasional maupun asing. Perlindungan $\mathrm{HKI}$ di Indonesia terutama yang berkaitan dengan masalah IG baru terbatas pada beberapa pasal yang bernaung dibawah UUM dan PP No. 51 tahun 2007 tentang IG. Perlindungan HKI tidak hanya sekedar sebagai alat pembangunan ekonomi tetapi yang lebih penting adalah sebagai alat perlindungan pembangunan ekonomi nasional, agar pengalaman didaftarkannya IG oleh negara lain tidak terulang kembali.

Dalam penerapan dan pelaksanannya terbukti bahwa perlindungan IG masih sangat sedikit, terutama yang dilakukan oleh para petani di daerah seperti para petani bawang merah, telur asin Brebes, teh hitam Kaligua dan beras hitam Sirampog di Kabupaten Brebes. Padahal begitu banyak manfaat yang dapat diperoleh sejalan dengan prinsip-prinsip dalam HKI antara lain Prinsip Keadilan, artinya memberikan hak kepada masyarakat Brebes selaku pemilik IG untuk dapat memperoleh hak-hak ekonomi dan hak moralnya. Prinsip Ekonomi, yaitu prinsip untuk dapat menikmati keuntungan bagi masyarakat Brebes terutama masyarakat petani. Prinsip Kebudayaan, yaitu bahwa perlindungan IG Bawang Merah
Brebes, telur asin Brebes, teh hitam Kaligua dan beras hitam Sirampog ini akan meningkatkan taraf hidup, peradaban dan martabat manusia di daerah ini, dan yang terahir adalah Prinsip Sosial, mengandung arti bahwa hak-hak yang diberikan oleh negara untuk kepentingan warga negaranya.

\section{Upaya Masyarakat Kabupaten Brebes dalam melindungi potensi IG}

Ketentuan UUM dan PP No 51 tahun 2007 sebagaimana telah disebutkan sebelumnya bahwa IG mendapat perlindungan setelah terdaftar atas dasar permohonan yang diajukan oleh:

1. Lembaga yang mewakili masyarakat Kabupaten Brebes

a. Pihak yang mengusahakan barang yang merupakan hasil alam atau kekayaan alam

b. Produsen hasil barang pertanian

c. Pembuat barang-barang hasil kerajinan tangan atau hasil industri; atau

d. Pedagang yang menjual barang tersebut

2. Lembaga yang diberi Kewenangan

3. Kelompok Konsumen

Ketiga komponen diatas adalah pihak-pihak yang dapat mendaftarkan Potensi IG di Kabupaten Brebes, berdasarkan hasil penelitian ketiga unsur tersebut belum berjalan dengan baik hal itu dikarenakan adanya beberapa faktor yaitu;

1. Tingkat pendidikan masyarakat rendah

2. Lemahnya kesadaran hukum masyarakat terhadap arti pentingnya upaya perlindungan hukum terhadap potensi IG yang ada di Kabupaten Brebes 
3. Besarnya biaya dan lamanya waktu yang dibutuhkan dalam proses pendaftarannya.

Upaya masyarakat Kabupaten Brebes dalam melindungi potensi IG adalah baru sebatas terbentuknya sistem klaster untuk komoditas unggulan oleh pemkab, pengujian produk hasil pertanian ke laboratorium penelitian, terbentuknya kelompok-kelompok tani dan terbentuknya koperasi. Adanya sosialisasi tentang IG di tahun 2010 yang lalu dinilai kurang efektif karena sampai dengan penelitian ini dilakukan belum terbentuknya masyarakat perlindungan Indikasi geografis/MPIG sebagai pihak yang concern atau pemerhati IG dari Kabupaten Brebes. Hal ini menunjukan bahwa tingkat kesadaran masyarakat terhadap hukum masih sangat lemah.

Seperti sudah disinggung sebelumnya bahwa perlindungan hukum $\mathrm{HKI}$ merupakan konsep yang sebelumnya tidak dikenal dalam sistem hukum Indonesia. HKI aslinya berasal dari konsep budaya hukum barat yang mengedepankan hak-hak individual, sedangkan Indonesia umumnya mengenal sistem hukum yang dilandasi asas kebersamaan dan kekeluargaan sehingga kehadiran HKI sangat sulit diterapkan dalam sistem hukum Indonesia.

Perlindungan hukum IG umumnya lebih banyak menyentuh masyarakat petani, karena IG melindungi potensi hasil-hasil pertanian dan perkebunan yang memiliki reputasi dan ciri khas tertentu, disamping kehutanan, perikanan kelautan, hasil-hasil kerajinan tangan dan industri tertentu lainnya. PP No. 51 tahun 2007 memiliki beberapa pasal yang agak rumit namun kehadiran

\footnotetext{
${ }^{19}$ Pedoman Tekhnis Pelaksanaan IG Tahun 2012, Direktorat Pengembangan Usaha dan Investasi, Direktorat Jenderal
}

PP ini seharusnya disambut baik oleh masyarakat Brebes untuk mengembangkan asset daerahnya. Perlindungan IG tidak memiliki jangka waktu selama ciri dan kualitas IG tersebut tetap terjaga, dengan demikian selain mendapatkan manfaat ekonomi, perlindungan hukum IG juga berfungsi sebagai sarana untuk menjaga kelestarian alam.

Penelitian lapangan tentang upaya masyarakat dalam melindungi potensi IG penulis berasumsi bahwa masyarakat Brebes belum memiliki kesadaran hukum tentang perlunya perlindungan potensi IG didaerahnya. Oleh karena itu agar potensi-potensi IG yang ada di daerah ini bisa berkembang dengan baik dan mendapatkan perlindungan hukum, maka pemberdayaan SDM dan pengembangan kelembagaan perlu ditingkatkan sebagai salah satu upaya perlindungan terhadap keaslian dan kekhasan produk berpotensi IG Kabupaten Brebes:

\section{Pemberdayaan SDM}

Pemberdayaan SDM dalam pengembangan IG bertujuan untuk:19

a) Meningkatkan kemampuan, kapasitas dan wawasan dikalangan masyarakat agar menjadi pengelola usaha agribisnis komoditas unggulan dan spesial yang berdaya saing melalui proses sosialisasi

b) Selain itu, pemberdayaan ini dimaksudkan untuk menumbuhkan kesadaran SDM dalam memanfaatkan potensi sumberdaya pertanian yang dimilikinya untuk mengembangkan usaha agribisnis produk unggulan dan spesial di wilayahnya

c) Melalui, pemberdayaan ini diharapkan usaha agribisnis komoditas pertanian unggulan dan spesial akan tumbuh dan berkembang menjadi kawasan usaha agribisnis unggulan dan spesial yang

Pengolahan Dan Pemasaran Hasil Pertanian Kementrian Pertanian, hlm. 13 
berdaya saing secara berkelanjutan. Indikator keberhasilan dari kegiatan pemberdayaan tersebut adalah tumbuhnya minat untuk membangun MPIG. Diharapkan MPIG akan berkembang kemampuannya dalam mengelola, mengoptimalkan potensi yang ada dan menguatkan kelembagaan kelompok tani dalam pengembangan usaha agribisnis produk unggulan dan spesial mulai dari tahap budidaya hingga pemasarannya.

2. Pengembangan Kelembagaan

Pengembangan kelembagaan MPIG dilakukan melalui pengembangan kelembagaan ekonomi, pengembangan jaringan usaha dan fasilitas terhadap akses pemasaran secara bertahap, dinamis dan berkelanjutan.

\section{B. Simpulan dan Saran}

a. Simpulan

Pemerintah Kabupaten Brebes belum memiliki format yang jelas tentang pengembangan potensi IG. Adanya Peraturan Daerah diharapkan semua kegiatan inventarisasi dan dokumentasi potensi IG akan dapat diakomodir dengan baik oleh dinas-dinas terkait yang ada di daerah, sehingga potensi IG di Kabupaten Brebes mendapatkan perlindungan hukum guna pengembangan ekonomi masyarakat lokal. Oleh karena Masyarakat Brebes belum mendaftarkan potensi IG nya dan Pemerintah Kabupaten Brebes juga belum memiliki peraturan daerah yang khusus untuk melindungi IG maka perlindungan hukum potensi IG Kabupaten Brebes mengacu pada aturan yang berlaku secara umum, sehingga perlindungan hukum potensi IG Kabupaten Brebes dapat dilakukan dengan:

1) Perlindungan Hukum Preventif

2) Perlindungan Hukum Represif

Upaya masyarakat Kabupaten Brebes dalam melindungi potensi IG adalah terbentuknya sistem klaster untuk komoditas unggulan oleh pemkab, pengujian produk hasil pertanian ke laboratorium penelitian, terbentuknya kelompok-kelompok tani dan terbentuknya koperasi. Adanya sosialisasi tentang IG di tahun 2010 yang lalu dinilai kurang efektif karena sampai dengan penelitian ini dilakukan belum terbentuknya masyarakat perlindungan Indikasi geografis/MPIG sebagai pihak yang concern atau pemerhati IG dari Kabupaten Brebes.

b. Saran

Agar potensi IG di Kabupaten Brebes mendapatkan perlindungan hukum melalui pendaftaran, maka Pemerintah Kabupaten Brebes beserta dinas-dinas terkait serta masyarakat untuk segera membentuk MPIG baik Bawang Merah Brebes, Telur Asin Brebes, Beras Hitam Sirampog dan Teh Hitam Kaligua sebagai pihak yang mengajukan permohonan pendaftaran agar masyarakat dapat lebih sejahtera dan ekonomi lokal dapat lebih ditingkatkan. Syarat mutlak pendaftaran harus mengisi Buku Persyaratan yang menguraikan tentang karakteristik dan ciri khas IG tersebut dan yang dapat mengisinya adalah MPIG yang bersangkutan.

\section{DAFTAR PUSTAKA}




\section{A. Buku}

Ashofa, Burhan, 1996, Metode Penelitian Hukum, Rineka Cipta, Jakarta

Hadjhon, Philipus M. 1988, Perlindungan Hukum Bagi Rakyat Indonesia, Bina IImu, Surabaya

Jened, Rahmi, 2007, Hak Kekayaan Intelektual Penyalahan Hak Eksklusif, Universitas Airlangga, Surabaya

Mayana, Ranti Fauza, 2004, Perlindungan Desain Industri di Indonesia Dalam Era Perdagangan Bebas, Grasindo, Jakarta

Munir, Risfan dan Fitanto, Bahtiar, 2008, Pengembangan Ekonomi Lokal Partisipatif: masalah, Kebijakan dan Panduan Pelaksanaan Kegiatan, Local Governance Support Program (LGSP), Jakarta

Mertokusumo, Sudikno, 2010, Mengenal Hukum Suatu Pengantar, Universitas Atmajaya, Yogyakarta

Risang Ayu, Miranda, 2006, Memperbincangkan Hak Kekayaan Intelektual Indikasi Geografis, Alumni, Bandung

Rahardjo, Satjipto, 2003, Sisi-sisi Lain dari Hukum di Indonesia, Harian Kompas, Jakarta

Soekanto, Soerjono, 2005, Faktor-Faktor Yang Mempengaruhi Penegakkan Hukum, Cet.ke-6, Raja Grafindo Persada, Jakarta

Sommeng, Andy Noorsaman dan Damar Sasongko, Agung, 2008, Indikasi Geografis: Sebuah Pengantar, Direktorat Jenderal HKI (DJHKI), Jakarta

Sutedi, Adrian, 2009, Hak Atas Kekayaan Intelektual, Ed.1 Cet-1, Sinar Grafika, Jakarta

Soemitro, Ronny Hamitijo, 1990, Metode Penelitian Hukum dan Jurimetri, Ghalia Indonesia, Jakarta

Sunggono, Bambang, 1996, Metodologi Penelitian Hukum, PT. Raja Grafindo Persada, Jakarta

Soekanto, Soerjono, 2008, Pengantar Penelitian Hukum, Universitas Indonesia, Jakarta

Sugiyono, 2012, Memahami Penelitian Kualitatif, Alfabeta, Bandung

Syahrani, Ridwan dan Astarini, Dwi Rezeki, 2009, Penghapusan Merek Terdaftar, Alumni, Bandung

Tanya, Bernard L. et al, 2010, Teori Hukum Strategi Tertib Manusia Lintas Ruang dan Generasi, cet-3, Genta Publishing, Yogyakarta
B. Jurnal, makalah dan lainnya

Amien Soetiarto, Noegroho, 2000, Hak Kekayaan Intelektual dan Kekayaan Intelektual Tradisional dalam Konteks Otonomi Daerah, Mimbar Hukum Nomor 34/II/2000

Direktorat Kerjasama dan Perdagangan Internasional, 2004, Peningkatan Nilai Tambah Indonesia Dengan Pengembangan Indikasi Geografis, Direktorat Kerjasama Multilateral, Jakarta

Junus, Emawati, 2007, Makalah PPT dalam Pentingnya Perlindungan Indikasi Geografis Sebagai Bagian Dari HKI dan Pelaksanaannya di Indonesia, Ditjen HKI, Jakarta

Ramly, Tatty dan Sumiyati, Yety, et al, 2010, Urgensi Pendaftaran Indikasi Geografis Ubi Cilembu untuk meningkatkan IPM, Mimbar Vol. XXVI, No. 1 (Januari-Juni 2010):81-91

Ramli, Tatty dan Sumiyati, Yeti, 2008, Implikasi Pendaftaran Indikasi Geografis Terhadap Potensi Peningkatan Pertumbuhan Ekonomi Masyarakat, Jurnal Hukum Bisnis, vol. 27-No.4-Tahun 2008

Riyaldi, H., 2008, Perlindungan Indikasi Geografis Manfaat dan Tantangannya, Media HKI, Vol.V/No.04/Agustus 2008, Departemen Hukum dan HAM RI, Direktorat Jenderal Hak Kekayaan Intelektual, Jakarta

Sumiyati, Yeti, dkk., 2008, Kajian Yuridis Sosiologis mengenai Indikasi Geografis sebagai sumber PAD, MIMBAR, VoIXXIV, No 1

Septiono, Saky, 2009, Perlindungan Indikasi Geografis dan Potensi Indikasi Geografis Indonesia, Makalah dalam Pelatihan Konsultan HKI 2009, Ditjen HKI

Workshop "Geographical Indication In Indonesia" Media HKI Depkumham, vol II/No.1 April 2004

\section{Artikel Internet}

Disperindag.brebeskab.go.id/data_industri., diakses tanggal 2 Desember 2013

Kelebihan Bawang Merah dari Lumbung Bawang Merah Brebes, Pasar bawangbrebes.blogspot.com, diakses 28 Nopember 2013.

www.jateng prov.go.id., diakses tanggal 15 Nopember 2013

Mabruri Sirampog, wordpress.com, diakses tanggal 15 Maret 2014 
www.Koran Lokal.com, 14 Juni 2011, diakses tanggal 17 Nopember 2013

id.wikipedia.org/wiki/Daftar_provinsi_di_Indonesia, diakses tanggal 29 Desember 2013

www.dgip.go.id/indikasi-geografis, diakses 12 Nopember 2013

www.Sindonews.com/2012/11/15/brebes-siapkembangkan-ekonomi-kerakyatan, diakses tanggal 23 Nopember 2013

www.diradio.net/2012/rasa-khas-teh-hitamkaligua, diakses 10 Februari 2014 ptpnix.co.id/manfaat-kesehatan-teh-hitam, diakses 10 Februari 2014

Brebeskab.bps.go.id, diaksestanggal 17 Desember 2013

\section{Peraturan Perundang-undangan} Undang-Undang Dasar 1945

Undang-Undang Nomor 14 Tahun 1997 TentangMerek

Undang-Undang Nomor 15 Tahun 2001 TentangMerek

Peraturan Pemerintah Nomor 51 Tahun 2007 Tentang Pendaftaran Indikasi Geografis 